Care: Jurnal Ilmiah Ilmu Kesehatan Vol.8, No.3, 2020, hal 326-337

Tersedia online di https://jurnal.unitri.ac.id/index.php/care

ISSN 2527-8487 (online)

ISSN 2089-4503 (cetak)

\title{
PEMBERDAYAAN KELUARGA DALAM MENURUNKAN TINGKAT KECEMASAN PASIEN GGK DENGAN HEMODIALISA
}

\author{
Oktavia Wulandari ${ }^{1}$, Dhina Widayati ${ }^{2}$ \\ 1), 2) Stikes Karya Husada Kediri, Pare Kediri, Jawa timur \\ E-mail : budinawida@gmail.com
}

\begin{abstract}
Chronic kidney failure (CKD) is a pathological condition in the kidney with diverse etiologies, resulting in progressive decline in kidney function, and in general must undergo hemodialysis therapy. In patients with hemodialysis therapy, anxiety often arises with the therapentic procedures that are given so that the system needs support from the family. This study wanted to determine the effect of family empowerment on anxiety levels of chronic renal failure patients with hemodialysis. The pre-experimental design was the design in this study with a population of 36 patients and a sample size of 22 patients obtained through purposive sampling. This study used a questionnaire instrument and the data obtained were analyzed using the Wilcoxon Sign Rank. Test. The measurement results on the level of anxiety before the intervention showed $63 \%$ in the level of severe anxiety and after the intervention showed $46 \%$ in the category of moderate anxiety. P-value in the statistical test shows 0.003 which means that there is an influence of family empowerment with anxiety level of CRF patients undergoing bemodialysis therapy. Family empowerment can reduce the level of anxiety for patients undergoing hemodialysis in the Hemodialysis Room of RSUD. Mardi Waluyo Blitar. Family empowerment provides assistance, solutions, support, so that it can be used to overcome the anxiety experienced by patients undergoing hemodialysis.
\end{abstract}

Keyword : Anxiety; CHF; family empowerment; hemodialysis.

\begin{abstract}
ABSTRAK
Gagal ginjal kronis (GGK) merupakan suatu kondisi patologis pada ginjal dengan penurunan fungsi ginjal yang progresif yang pada umumnya harus menjalani terapi hemodialisa. Pada pasien dengan terapi hemodialisa sering kali timbul kecemasan dengan prosedur terapi yang diberikan sehingga perlu support sistem dari keluarga. Penelitian ini ingin mengetahui pengaruh pemberdayaan keluarga terhadap tingkat kecemasan pasien GGK dengan hemodialisa. Desain pra eksperimen menjadi desain dalam penelitian ini dengan jumlah populasi 36 pasien dan besar sampel 22 pasien yang diperoleh melalui purposive sampling. Data diperoleh melalui kuesioner dan dianalisa menggunakan Wilcoxon
\end{abstract}

Cara mengutip: Wulandari, Oktavia \& Widayati, Dhina. (2020). Pemberdayaan Keluarga dalam Menurunkan Tingkat Kecemasan Pasien GGK dengan Hemodialisa.Care:Jurnal Ilmiah Ilmu Kesehatan, 8(3), 326-337

Retrieved from https://jurnal.unitri.ac.id/index.php/care/article/view/1806 
Sign Rank Test. Hasil pengukuran pada tingkat kecemasan sebelum intervensi menunjukkkan $63 \%$ dalam tingkat kecemasan berat dan sesudah intervensi menunjukkan $46 \%$ dalam kategori tingkat kecemasan sedang. P-value pada uji statistik menunjukkan 0,003 yang artinya pemberdayaan keluarga berpengaruh terhadap tingkat kecemasan pasien GGK yang menjalani terapi hemodialisa. Pemberdayaan keluarga dapat menurunkan tingkat kecemasan pasien GGK dengan terapi Hemodialisa di RSUD. Mardi Waluyo Blitar. Pemberdayaan keluarga memberikan bantuan, solusi, support, sehingga membuat pasien merasa tenang dan kecemasannya berkurang.

Kata Kunci : GGK; hemodialisa; kecemasan; pemberdayaan keluarga.

\section{PENDAHULUAN}

Gagal ginjal kronis (GGK) merupakan kondisi patologis pada ginjal dengan penurunan fungsi secara progresif karena berbagai hal (Setiyohadi, 2009). Penderita GGK dihadapkan pada fakta manajemen penatalaksanaan GGK dengan berbagai terapi obat, pembatasan cairan, mnajemen diet hingga hemodialisa (Nian, 2017). Hal inilah salah satu hal yang membuat penderita merasakan kecemasan terhadap proses penyakit dan proses pengobatan (Jangkup, 2015).

Data Indonesia Renal Registry pada tahun 2015 menunjukkan jumlah pasien GGK yang menjalani terapi hemodialisa terus meningkat $10 \%$ setiap tahunnya, sebanyak 15.424 orang penduduk Indonesia mengalami ketergantungan pada hemodialisa (IRR, 2015). Data studi pendahulan di RSUD. Mardi waluyo Blitar didapatkan $40 \%$ dari 10 pasien menyatakan sangat khawatir dengan kondisinya.

Hemodialisa merupakan tindakan penggantian fungsi ginjal pada pasien GGK yang berlangsung secara terusmenerus sepanjang hidup pasien (Supriyadi, 2011). Seseorang yang menjalani terapi hemodialisa akan mengalami perubahan hampir seluruh aspek kehidupannya, baik secara fisik terkait efek samping hemodialisa, yakni : sakit kepala, kram otot, mual, muntah, dan hipotensi maupun secara psikologis, yakni kecemasan, (Canisti 2007). Dampak kecemasan sering diabaikan oleh tenaga kesehatan seperti dokter atau perawat, padahal psikologis berperan besar dalam mengoptimalkan keberhasilan terapi hemodialisis ini (Zahrofi, et al., 2013). Kecemasan adalah kekhawatiran terhadap sesuatu yang sumbernya kurang spesifik yang berkaitan dengan perasaan tidak pasti dan 
Care: Jurnal Ilmiah Ilmu Kesehatan Vol .8, No.3, 2020, hal 326-337

dapat menimbulkan perasaan tidak berdaya (Wartilisna, et al., 2015). Respon kecemasan masing masing individu berbeda dan sering nampak dari sikap khawatir, gelisah, tidak tenang, yang seringkali disertai dengan keluhan fisik (Maramis, 2010).

Kecemasan pada klien GGK yang menjalani hemodialisa dapat timbul karena pasien merasa tidak menerima fakta bahwa dirinya sakit, adanya komplikasi dalam terapi hemodialisa seperti kram otot, perdarahan, hipoksia, gangguan pencernaan, rasa gatal dan pembekuan darah, serta hidupnya harus bergantung pada alat serta orang lain (Armiyati, 2016). Aktivitas kehidupannya terganggu dengan adanya rutinitas terapi hemodialisa yang dilakukan 2 kali dalam seminggu secara terus menerus sepanjang hidupnya (Mayuda, 2017). Apabila rasa cemas berlangsung dalam waktu yang panjang dan tidak ditangani dengan baik, dapat berakibat penyakit yang dialaminya bisa bertambah parah serta bisa menimbulkan komplikasi penyakit lainnya (Rosdiana, 2014). Kecemasan yang terkelola dengan baik dapat meningkatkan produktivitas seseorang dapat terjaga untuk hidup yang lebih berkualitas (Daniswara, 2015).
Salah satu manajemen kecemasan pada klien yang menjalani hemodialisa dapat ditangani dengan penerapan intervensi keperawatan pemberdayaan keluarga (Daniswara, 2015).

Pemberdayaan keluarga adalah upaya kolaborasi dengan keluarga dalam merawat pasien dengan meningkatkan pengetahuan keluarga sehingga keluarga mampu turut serta mengidentifikasi masalah, merencanakan dan melakukan pemecahan masalah (Pramastri, 2015). Keluarga merupakan sebuah sistem yang saling memengaruhi (Patriani, 2010). Pada klien yang menjalani hemodialisa disini peran keluarga lebih banyak dibutuhkan. Program yang berfokus pada pemberian informasi pada keluarga berkaitan dengan penyakit kronis dalam keluarga dapat memperlihatkan perbaikan dalam penatalaksanaan penyakit dan perawatannya (Friedman, 2010). Tujuan penelitian ini untuk mengetahui pengaruh pemberdayaan keluarga terhadap tingkat kecemasan pasien GGK dengan hemodialisa.

\section{METODE PENELITIAN}

Desain yang digunakan pada penlitian ini adalah pra eksperimen dengan jumlah populasi 36 orang dan besar samel 22 
yang diperoleh melalui purposive sampling. Pada penelitian ini family empowerment sebagai variabel independen. Kecemasan sebagai variabel dependennya. Penelitian berlangsung selama 1 bulan dengan frekuensi pemberian intervensi perminggu 2 kali selama 2 minggu, pertemuan dilakukan 4 sesi dengan durasi persesi 40 menit. Tempat penilitian di RSUD Mardi Waluyo Blitar. Analisa data menggunakan uji Wilcoxon Sign Rank test.

\section{HASIL}

Tabel 1. Distribusi Frekuensi Tingkat Kecemasan Sebelum Intervensi

\begin{tabular}{ccc}
\hline Tingkat Kecemasan & $\mathbf{f}$ & $\mathbf{( \% )}$ \\
\hline Tidak Cemas & 0 & 0 \\
Ringan & 2 & 9,1 \\
Sedang & 6 & 27,3 \\
Berat & 14 & 63,6 \\
\hline Total & 22 & 100 \\
\hline
\end{tabular}

Tabel 1 menunjukkan sebagian besar $(63,6 \%) 14$ responden pre-intervensi mengalami kecemasan dalam kategori Kecemasan Berat.

Berdasarkan Tabel 2 diketahui bahwa tingkat kecemasan sesudah diberikan intervensi menunjukkan adanya penurunan tingkat kecemasan yaitu kecemasan ringan $(27,3 \%) 6$ pasien, kecemasan sedang $(45,5 \%) 10$ pasien dan kecemasan berat $(27,3 \%) 6$ pasien

Tabel 2. Distribusi Frekuensi Tingkat Kecemasan Sesudah Intervensi

\begin{tabular}{ccc}
\hline Tingkat Kecemasan & $\mathbf{f}$ & $\mathbf{( \% )}$ \\
\hline Tidak Cemas & 0 & 0 \\
Ringan & 3 & 27,3 \\
Sedang & 5 & 45,5 \\
Berat & 3 & 27,3 \\
\hline Total & 11 & 100 \\
\hline
\end{tabular}

Hasil analisis seperti tertera pada Tabel 3 menggunakan uji wilcoxon dengan skala ordinal Nilai rata-rata 29,5455 sebelum diberikan intervensi, dan sesudah diberikan menjadi 20,7273. Tingkat kecemasan memiliki nilai jarak yaitu 8.2020 dan setelah diberikan intervensi pemberdayaan keluarga terjadi perubahan menjadi 7.07235. Pemberian intervensi menunjukkan bahwa sebelum diberikan intervensi dengan nilai minimum 12 sedangkan sesudah diberikan intervensi mengalami penurunan dengan nilai 11 . Besar pengaruh sebelum diberikan intervensi dengan nilai 39 yang mengalami penurunan dengan nilai 30 . Hasil analisa statistik diketahui probabilitas $p$-value $=0,003$ menyatakan pemberdayaan keluarga mempengaruhi kecemasan pasien gagal ginjal kronik dengan terapi hemodialisa di RSUD. Mardi Waluyo Blitar. 
Care: Jurnal Ilmiah Ilmu Kesehatan Vol .8, No.3, 2020, hal 326-337

Tabel 3. Data Tingkat Kecemasan Sebelum dan Sesudah Intervensi

\begin{tabular}{lccccc}
\hline Tingkat Kecemasan & $\mathbf{N}$ & Mean & Std. Deviation & Min & Max \\
\hline sebelum & 22 & 29,5 & 8,2 & 12,00 & 39,0 \\
sesudah & 22 & 20,7 & 7,07 & 11,00 & 30,0 \\
\hline Valid N & 22 & & & & \\
P-value $=0,003$ & $\alpha=0,05$ & & & \\
\hline
\end{tabular}

\section{PEMBAHASAN}

\section{Tingkat Kecemasan Sebelum}

\section{Intervensi}

Berdasarkan fakta dari hasil penelitian sebelum diberikan intervensi pemberdayaan keluarga di RSUD. Mardi Waluyo Blitar, sebagian responden mengalami kecemasan berat dengan prosentase $(63,6 \%)$.

Penelitian ini sejalan dengan pendapat Andri (2012) bahwa pasien GGK dengan terapi hemodialisa sering merasakan frustasi, takut dan marah akibat penyakit kronis yang diderita yang membuat, perubahan gaya hidup dan juga akibat terapi yang harus dijalani. Demikian juga dengan hasil penelitian ini setelah diberikan kuisioner dengan menggunakan skala HARS, pasien mengalami kecemasan fisik meliputi nyeri otot kedutan, gangguan pencernaan, perut terasa kembung, sering kencing, mulut kering, mudah berkeringat, sakit kepala serta nafas pendek dan cepat. Serta mengalami kecemasan psikologis yang meliputi gemetar, gelisah, tidak dapat istirahat dengan nyenyak, sulit berkonsetrasi, sedih, mudah tersinggung, takut akan pikiran sendiri, dan merasakan nyeri.

Berdasarkan hasil penelitian didapatkan prosentase terbanyak yang mengalami kecemasan sebesar $(45,4 \%)$ berusia $>51$ tahun. Menurut (Kemenkes RI, 2015) usia berhubungan dengan prognosa dan tingkat keparahan. Pada usia 50 tahun keatas peluang komplikasi yang memperberat fungsi ginjal lebih tinggi bila dibandingkan dengan usia dibawah 40 tahun. Pada studi ini didapatkan bahwa beberapa pasien ditemukan adanya komplikasi penyakit diabetes militus. Menurut peneliti, Pada umumnya kualitas hidup seseorang berbanding terbalik dengan usia. Penderita gagal ginjal kronik yang menjalani hemodialisa yang mempunyai kecemasan berat pada kelompok usia produktif merasa terpacu untuk sembuh karena masih banyak tanggungan yang harus diselesaikan. 
Penderita pada usia tua cenderung lebih pasrah dan kurang motivasi dalam menjalani terapi hemodialisa.

Berkaitan dengan kriteria jenis kelamin, sebagian besar pasien dengan jenis kelamin laki - laki (63,6\%). Menurut (Budiarto dan Anggraini, 2008), pada beberapa penyakit terdapat perbedaan frekuensi antara laki-laki dan perempuan karena perbedaan aktivitas, pekerjaan, kebiasaan hidup, kondisi fisiologis, dan genetika. Dari hasil observasi dan wawancara pada penelitian tersebut menyatakan bahwa pasien laki-laki kurang memperhatikan gaya hidup, yakni: kebiasaan merokok, gemar mengkonsumsi makanan yang tinggi lemak. Hal ini sejalan dengan studi yang dilakukan oleh Widayati (2015), insiden GGK sering terjadi pada usia dewasa berkaitan dengan gaya hidup (konsumsi minuman berenergi supaya tidak mudah cepat lelah) dan pola makan yang tinggi lemak.

Berdasarkan pekerjaan responden didapatkan bahwa hampir setengah pasien (36,4\%) yang menjalani hemodialisa pekerjaannya adalah PNS dan Wiraswasta. Menurut Angraini (2002) menyatakan frekuensi dan distribusi penyakit berkaitan dengan jenis pekerjaan karena sebagian waktu dihabiskan ditempat kerja dengan suasana lingkungan yang beragam.

Berdasarkan lama menjalani hemodialisa yang mengalami kecemasan berat menunjukkan bahwa sebagian besar $(63,6 \%)$ kurang dari 6 bulan. Menurut Tokala 2(015), seseorang yang didiagnosis penyakit ginjal kronik stadium akhir akan mengalami ketidakseimbangan fisik dan psikologisnya. Sejala dengan penelitian Nadia (2015) menyatakan bahwa berdasarkan lamanya menjalani hemodialisa didapatkan nilai rerata kecemasan lebih tinggi pada awal <6 bulan. Pasien belum mampu beradaptasi dengan baik pada tahap awal menjalani hemodialisa, pasien merasa tidak menerima fakta bahwa dirinya sakit, adanya komplikasi dalam terapi hemodialisa seperti kram otot, gangguan pencernaan, rasa gatal dan pembekuan darah, serta hidupnya harus bergantung pada alat serta orang lain. Aktivitas kehidupannya terganggu dengan adanya rutinitas terapi hemodialisa yang dilakukan 2 kali dalam seminggu secara terus menerus sepanjang hidupnya tentu juga membuatnya jenuh (Mayuda,2017). 
Care: Jurnal Ilmiah Ilmu Kesehatan Vol .8, No.3, 2020, hal 326-337

\section{Tingkat Kecemasan Sesudah \\ Intervensi}

Berdasarkan fakta dari penelitian dengan menggunakan analisis uji wilcoxon sebelum dan sesudah diberikan intervensi pemberdayaan keluarga di RSUD. Mardi Waluyo Blitar, sebelum diberikan intervensi sebagian responden mengalami kecemasan berat dengan prosentase $(63,6 \%)$ kemudian setelah diberikan intervensi pemberdayaan keluarga tingkat kecemasan berat mengalami penurunan dengan prosentase $(27,3 \%)$.

Pada penelitian ini sebelum diberikan perlakuan berupa pemberdayaan keluarga, anggota keluarga diidentifikasi sejauh mana potensi keluarga dalam merawat anggota keluarga pada saat menjalani hemodialisa serta seberapa jauh anggota keluarga mengetahui tentang hemodialisa, gagal ginjal kronik, penyebab kecemasan. Kemudian anggota keluarga diberikan intervensi pemberdayaan keluarga menggunakan modul dengan metode pendidikan kesehatan mengenai (terapi hemodialisa, gagal ginjal kronik dan tingkat kecemasan), bimbingan dan konseling serta demonstrasi berbagai cara dalam memberikan asuhan keperawatan (mewajibkan anggota keluarga untuk memotivasi anggota keluarga agar rutin untuk menjalani terapi hemodialisa, mewajibkan anggota keluarga untuk menemani anggota keluarga yang sedang menjalani terapi hemodialisa, mewajibkan anggota keluarga untuk memberikan kompres hangat saat pasien merasakan nyeri, mewajibkan anggota keluarga dengan memberikan sentuhan terapeutik saat pasien merasakan gatal dan nyeri saat menjalani hemodialisa, mewajibkan anggota keluarga dengan memberikan makan dan minum, mewajibkan anggota keluarga menjadi pendengar yang baik, penuh kasih sayang, tidak menghakimi saat anggota keluarga mengeluh tentang penyakit dan masalah lainnya). Setelah diberikan pemberdayaan, anggota keluarga memberikan intervensi langsung berupa bentuk-bentuk pemberdayaan kepada anggota keluarga yang mengalami kecemasan berat, sedang dan ringan pada pasien gagal ginjal kronik yang menjalani hemodialisa. Evaluasi kepada anggota keluarga berupa hambatan apa saja yang didapatkan, apakah bentuk-bentuk dari pemberdayaan keluarga tersebut benarbenar dilakukan atau tidak. Intervensi dilakukan sebanyak 2 kali dalam seminggu selama 2 minggu dengan waktu 40 menit setiap pertemuan. Dalam proses pemberian intervensi masing-masing daya tangkap anggota keluarga tidak sama 
karena setiap orang mempunyai mekanisme koping dan kualitas hidup yang berbeda.

Berdasarkan fakta hasil penelitian, peneliti berpendapat bahwa dengan diberikan intervensi pemberdayaan keluarga dapat menurukan tingkat kecemasan. Pada penelitian ini, usia, jenis kelamin, tingkat pendidikan, status hubungan dengan keluarga, serta tinggal serumah atau tidak dengan penderita sangat berpengaruh dalam menurunkan tingkat kecemasan pasien gagal ginjal kronik yang menjalani hemdoialisa. Intervensi yang diberikan kepada 11 responden didapatkan bahwa sebelum diberikan intervensi sebagian besar responden $\quad(63,6 \%)$ mengalami kecemasan berat, hampir setengah responden $(27,3 \%) \quad$ mengalami kecemasan sedang dan sebagian kecil responden $(9,1 \%)$ mengalami kecemasan ringan. Setelah diberikan intervensi pemberdayaan keluarga adanya penurunan yakni hampir setengah responden $(27,3 \%) \quad$ mengalami kecemasan berat, hampir setengah responden $(45,5 \%)$ mengalami kecemasan sedang dan hampir setengah responden $(27,3 \%) \quad$ mengalami kecemasan ringan. Peneliti menyimpulkan dari penurunan kecemasan berat yang signifikan dipengaruhi karena anggota keluarga yang berpendidikan tinggi (S1), jenis kelamin (perempuan), usia (23-33) dewasa muda, status hubungan (anak, ibu, suami), tinggal serumah, dalam hal tersebut perempuan lebih bisa memahami dan mengerti, lebih telaten dalam memberikan asuhan keperawatan dibandingkan laki-laki yang umunya lebih cuek dan bersikap dingin. Pendidikan yang tinggi juga mempengaruhi daya tangkap penerimaan informasi yang diberikan, mempunyai perkiraan yang tepat dalam mengatasi kejadian sehingga dapat membantu pasien tersebut dalam membuat keputusan serta hubungan keluarga yang tinggal serumah akan lebih bisa dipantau kondisinya pada anggota keluarga yang sedang mengalami kecemasan, hubungan yang terjalin baik dan harmonis dalam keluarga dapat menurunkan kecemasan.

\section{Pemberdayaan keluarga dan kecemasan}

Berdasarkan fakta dari hasil penelitian dengan menggunakan uji wilcoxon diketahui bahwa sebelum diberikan intervensi pemberdayaan keluarga yang mengalami kecemasan sebagian besar dalam kategori berat. 
Care: Jurnal Ilmiah Ilmu Kesehatan Vol .8, No.3, 2020, hal 326-337

Hasil penelitian menyatakan setelah diberikan intervensi pemberdayaan terdapat perbedaan yang signifikan. Perubahan tingkat kecemasan ditandai dengan penurunan tingkat kecemasan sebagian pasien dalam kategori sedang dan ringan. Menurut Muhtar (2013) menyebutkan beberapa faktor yang dapat memengaruhi penurunan kecemasan seseorang diantaranya dukungan anggota keluarga. Ratna (2010) menyatakan dukungan dari keluarga dapat menjadi upaya preventif untuk menurunkan kecemasan dan memiliki peranan penting dalam menghadapi masalah (kesehatan). Dengan diberikan intervensi pemberdayaan keluarga dengan menggunakan modul, pengetahuan keluarga dan pasien meningkat, keluarga dan pasien saling terbuka (anggota keluarga yang mengalami kecemasan lebih sering berbagi cerita, lebih sering sharing tentang masalah atau hambatan yang sedang dialami, anggota keluarga dan pasien saling bertukar pendapat dan lebih menghargai), keluarga dan pasien saling memotivasi (anggota keluarga yang menjalani terapi lebih semangat untuk melakukan terapi secara rutin), koping keluarga meningkat dan status kesehatan pasien semakin membaik.
Keluarga merupakan sebuah sistem yang saling memengaruhi. Keterlibatan dengan keluarga membuat perasaan aman, nyaman, tenang, serta dukungan emosional yang akan berpengaruh pada masalah psikologis terutama pada tingkat kecemasannya. Sebagian besar perubahan psikologis terjadi akibat aktifitas dari sistem neuroendokrin yang dikendalikan oleh hipotalamus untuk memproduksi ACTH sehingga menstimulasi medula adrenal untuk melepaskan hormon epinepfin (Priambodo, 2015).

Pada perubahan tingkat kecemasan seseorang selain pengaruh dari anggota keluarga yang memberikan asuhan keperawatan dan caregiver, adanya faktor lain yang memengaruhi kecemasan yaitu : usia, pengalaman, aset fisik, dan juga pengetahuan dan pendidikan serta adanya komplikasi saat menjalani hemodialisa. Hasil penelitian menunjukkan setelah anggota keluarga diberikan intervensi pemberdayaan keluarga menggunakan modul, anggota keluarga lebih peduli dan memahami jika semakin baik hubungan dengan anggota keluarga akan menurunkan tingkat kecemasan dan jika tidak ditangani dengan baik kecemasan yang berlebihan dapat menyebabkan psikosomatik. 
Hasil analisis pada studi ini melalui uji wilcoxon didapatkan p-value 0.003 menandakan ada pengaruh pemberdayaan keluarga terhadap tingkat kecemasan. Hal ini dikuatkan oleh teori Friedman (2010) yang menyatakan dengan keterlibatan keluarga, maka keluarga menjadi lebih mampu dalam mengambil keputusan dengan penyedia pelayanan kesehatan dalam meningkatkan tingkat kenyamanan pada anggota keluarga yang mengalami penyakit kronis. Sehingga masalah kecemasan dengan kategori berat, sedang dan ringan dapat teratasi.

Berdasarkan hasil dari fakta yang didapatkan perubahan tingkat kecemasan dengan menggunakan intervensi pemberdayaan masing-masing respon setiap individu berbeda, meskipun dengan stimulus yang sama. Hal ini disebabkan karena adanya faktor perbedaan pekerjaan, pendidikan, pengetahuan, tingkat usia, kebiasaan hidup, genetik atau kondisi fisiologis.

\section{KESIMPULAN}

Pemberdayaan keluarga berpengaruh terhadap tingkat kecemasan pasien GGK dengan hemodialisa. Pemberdayaan keluarga memberikan bantuan, solusi, support, sehingga dapat menurunkan tingkat kecemasan pasien GGK dengan hemodialisa.

\section{UCAPAN TERIMA KASIH}

Terima kasih kami sampaikan kepada para responden dan RSUD Mardi Waluyo Blitar.

\section{REFERENSI}

Andri. (2013). Gangguan psikiatrik pada pasien penyakit ginjal kronik. Bagian Psikiatri, Fakultas Kedokteran Universitas Kristen Krida Wacana. Jakarta

Anggraini, Y. Dwi. (2016). Kualitas Hidup Pasien Gagal Ginjal yang Menjalani Hemodialisis di RSUD Blambangan Banyuwangi. Naskah Publikasi Fakultas Kesehatan Masyarakat Universitas Jember.

Armiyati Y, Wuryanto E, Sukraeny N, (2016). Manajemen Masalah Psikososiospiritual Pasien Chronic Kidney Diseasse (CKD) dengan Hemodialisa di Kota Semarang. Rakernas Aipkema 12 "Temu Ilmiah Hasil Penelitian dan Pengabdian Masyarakat.

Budiarto Eko, Dewi Anggraeni. (2001). Pengantar Epidemiologi II. Jakarta: Buku Kedokteran EGC.

Canisti I. (2013). Kecemasan dan Depresi Pada Pasien Gagal Ginjal Kronik Yang Menjalani Terap Hemodialisa. Jurnal Psikologi Ulayat, 1(2):207-222.

Daniswara, S. (2015). Pengaruh dukungan Sosial terhadap Tingkat Kecemasan $p x$. GGK yang menjalani Hemodialisis di RSUD, dr. Soebandi Jember. Skripsi.Tidak diterbitkan, FKUJ.

Friedman, L. M. (2010). Buku ajar keperawatan keluarga: riset, teori, praktik. $\left(5\right.$ th $\left.^{\text {ed }}\right)$. Jakarta: EGC. 
Indonesian Renal Registry (IRR). (2015). 7th Report Of Indonesian Renal Registry

Jangkup J, Elim C, Kandou L. (2015). Tingkat Kecemasan Pada Pasien Penyakit Gagal Gnjal Kronik Yang Menjalani Hemodialisa di BLU RSUP Prof.DR.R.D.Kandou Manado. Jurnal e-clinic (ecl), Vol.3, No.1, Januari - April 2015.

Kementerian Kesehatan RI. (2015). Infodatin Pusat Data dan Informasi Situasi Lanjut usia di Indonesia.

Maramis, W.F. (2005). Catatan Ilmu Kedokteran Jiwa. Surabaya: Airlangga University Press.

Mayuda A, Chasani S, Saktini F. (2017). Hubungan Antara Lama Hemodialisa Dengan Kualitas Hidup Pasien Gagal Ginjal Kronik di Semarang. Jurnal Kedokteran Indonesia.

Muhtar. (2013). Jurnal Pemberdayaan Keluarga Dalam Peningkatan Self Efficacy Dan Self Care Activity Keluarga Dan Penderita Tb Paru. Diakses Pada tanggal 2 Desember 2017.

Nadia. (2015). Kecemasan pada penderitagagal ginjal kronisdi LaboratoriumDialisis Rumah Sakit Pusat TNI AUDr. Esnawan Antariksa. Diakses pada tanggal 15 juni 2015.

Nian A, Widayati D. (2017). Gangguan Pada Sistem Perkemihan Dan Penatalaksanaan Keperawatan. Yogyakarta: Budi Utomo (Depublish).

Patriani A, Paramastri I, Priyanto M. (2010). Pemberadyaan Keluarga Dalam Rehabilitasi Medik Paru Pada Penderita Penyakit Paru Obstruksi Kronik di Balai Pengobatan Penyakit Paru Yogyakarta.

Pramastri, I. Adina, A. Priyanto, A. (2015). Jurnal Pemberdayaan Keluarga Dalam Rebabilitasi Medik Paru Pada Penderita Penyakit Paru Obstruksi Kronik di Balai Pengobatan Penyakit
Paru Yogyakarta. Diakses Pada Tanggal 4 Desember 2017.

Priambodo, G. (2015). Caring Dalam Asuhan Keperawatan, Kategori Caring Berdasarkan Budaya. Tesis

Ratna. (2010). Dukungan Keluarga Untuk Menurunkan Kecemasan. Diakses Pada Tanggal 8 Maret 2019.

Rosdiana I, Yetty K, Sabri L. (2014). Kecemasan dan Lamanya Waktu Menjalani Hemodialisa Berhubungan Dengan Kejadian Insomnia Pada Gagal Ginjal Kronik. Jurnal Keperawatan Indonesia, 17 (2): 15 - 27.

Setiyowati A, Hastuti W. (2014). Hubungan Tingkat Pengetahuan Dengan Kecemsan Pasien Hemodialisa di RS PKU Muhammadiyah Surakarta. Jurnal Profesi, Maret-Agustus 2014.

Supriyadi, Wagiyo, Widowati. (2011). Tingkat Kualitas Hidup Pasien Gagal Ginjal Kronik Terapi Hemodialisis. Jurnal Kesehatan Masyarakat. Volume 6 No. 2 Oktober 2011 hal 107-112.

Taylor, E Shelley. (2009). Health Psychology (7thedition). New York: Mc GrawHill Inc.

Tokala B, Kandou L, Dundu A. (2015). Hubungan Antara Lamanya Menjalani Hemodialisa Dengan Tingkat Kecemasan Pada Pasien Dengan Penyakit Gagal Ginjal Kronik di RSUD Prof. Dr. R,D. Kandou Manado. Jurnal e-Clinic (ecl) ; 3 (1).

Wartilisna, Kundre, R. \& Babakal, A. (2015). Hubungan Tindakan Hemodialisa dengan Tingkat Kecemasan Klien Gagal Ginjal di Ruangan Dahlia RSUP Prof Dr. R. Kandou Manado. Ejournal Keperawatan, 3(1).

Widayati D, Lestari N. (2015). Peningkatan Kualitas Hidup Pada Penderita Gagal Ginjal Kronik Yang Menjalani Terapi Hemodialisa 
Melalui Psychologial Intervension di unit Hemodialisa RSUD Gambiran Kediri. Jurnal Ilmu Kesehatan ,3 (2).

Zahrofi, D. (2013). Pengaruh Pemberian

Terapi Murottal Al Quran Terhadap
Tingkat Kecemasan pada Pasien Hemodialisa di RS PKU Muhammadiyah Surakarta. Universitas Muhammadiyah Yogyakarta. 